\title{
Storage of Food Waste: Variations of Physical-Chemical Characteristics and Consequences on Biomethane Potential
}

\author{
Axelle Degueurce ${ }^{1} \cdot$ Sylvie Picard ${ }^{1} \cdot$ Pascal Peu $^{1} \cdot$ Anne Trémier $^{1}$
}

Received: 6 September 2018 / Accepted: 30 December 2018 / Published online: 10 January 2019

(c) The Author(s) 2019

\begin{abstract}
Food waste (FW) storage influences its physical-chemical characteristics and anaerobic digestion (AD) performance. In this work we present the results of two weeks long experiment where two types of FW were stored in dedicated cells $(10 \mathrm{~L}$ and $300 \mathrm{~L}$ ). Air was evenly flushed on the top surface of the substrates and then analyzed to identify and quantify possible gaseous emissions. Solid and liquid fractions were also periodically sampled and analyzed for total solid, volatile solid, ammonia and VFA contents. Results showed that storage initiated a hydrolysis process that modified the physical structure of FW, leading to the production of gases $\left(\mathrm{CH}_{4}, \mathrm{CO}_{2}\right.$ and ethanol) and a partly liquefied $\mathrm{FW}$. Depending on experimental conditions, a fraction between 61 and $70 \%$ of the initial substrate remained solid at the end of the storage period. In the liquid phase, a large proportion of lactic acid was measured with maximum contents of 5.9 and $14.8 \mathrm{~g} / \mathrm{kg}_{\mathrm{vs}}$ for the small-scale experiments with two different FW types and $3.0 \mathrm{~g} / \mathrm{kg}_{\mathrm{vs}}$ for the large-scale experiment, leading to inhibition of the biomethane potential (BMP) tests. In conclusion, this work showed that when storage of FW is needed before AD, the optimal time recommended to keep a high methane yield is one week.
\end{abstract}

Keywords Gaseous emissions · Anaerobic digestion $\cdot$ Lactic acid $\cdot$ Kitchen waste $\cdot$ Biomethane potential

\section{Statement of Novelty}

Studies about anaerobic digestion of food waste are increasing. However, most of them did not consider the effect of storage step (rarely avoidable) on the quality of the substrate. Thus, this study proposes to assess the influence of storage on food waste characteristics, including biomethane potential.

\section{Introduction}

In 2015, about $45 \%$ of municipal solid waste (MSW) generated in the European Union (EU) was recycled. By 2030, the objective is to reach $65 \%$ of MSW recycling and preparation for reuse [1]. Depending on the country, the amount

Axelle Degueurce

axelle.degueurce@irstea.fr

Anne Trémier

anne.tremier@irstea.fr

1 Irstea, UR OPAALE, 17 av. de Cucillé, CS 64427, 35044 Rennes, France of food waste (FW) generated by households represents 22 to $33 \%$ of the MSW produced [2] i.e. about 47 million tons [3]. Because it is an important source of organic matter and nutrients, this biomass can be recycled through many processes to produce added-value compounds such as bioethanol, enzymes, compost, biodegradable plastics or biogas through anaerobic digestion (AD) [4-6].

$\mathrm{AD}$ is a particularly interesting technology as it shows better environmental performance compared to the main current biowaste management i.e. landfilling, incineration, or even compared to composting, especially when focusing on global warming potential [7-9]. Indeed, this technology allows renewable energy production while greenhouse gas emissions are largely avoided. Taking advantage of these characteristics, several companies developed large scale centralized $\mathrm{AD}$ processes able to valorize the organic fraction of MSW [10-12]. More recently, micro-scale AD processes were developed and are being tested to locally valorize urban biowaste, including food waste [13, 14].

However, regardless of the AD technology used, FW has first to be collected from production sites before being valorized. In Europe, three main FW collection strategies exist: (i) the door-to-door model, corresponding to all 
systems with collection devices such as buckets, bins, bags or containers belonging to one single building or house; (ii) the bring point model, equivalent to the door-to-door model by using the same kind of collection devices but accessible for several buildings and houses; and (iii) the civic amenity sites model, where citizens bring the waste to enclosed sites operated by qualified staff [15]. The latter is quite rare for the disposal of $\mathrm{FW}$, but few cases were identified in Belgium [15]. The collection frequency of these systems ranges between once a day to twice a month depending on the city considered $[15,16]$ implying a nonavoidable storage period of the FW. After being delivered to the treatment plant FW is usually stored on site before $\mathrm{AD}$ for a time ranging between few hours and ten days [17]. Therefore, several storage steps occur from FW generation to valorization, and the spontaneous degradation of the initial waste [5] may affect the AD process.

Recent studies investigated the effect of storage on AD performance. Nilsson Påledal et al. [16] tested the effect of temperature $\left(6\right.$ or $\left.22{ }^{\circ} \mathrm{C}\right)$, collection method (use of plastic or paper bags) and storage time (0-21 days) on biomethane potential (BMP) of source separated household FW. They found that after 21 days of storage, all conditions led to a slight decrease of BMP values. The worst situation was observed with the use of paper bags at a storage temperature of $22{ }^{\circ} \mathrm{C}$. In this case, BMP value decreased from 135 to $75 \mathrm{NmL}_{\mathrm{CH} 4} / \mathrm{g}$ of fresh $\mathrm{FW}$, a trend that was linked to the loss of water and volatile solid contents during storage. Lü et al. [17] also studied the effect of storage time (0-12 days) on BMP performances with FW stored at $35{ }^{\circ} \mathrm{C}$ in small polystyrene centrifuge tubes $(50 \mathrm{~mL})$, without bags nor lids, but covered by perforated Parafilm to mimic anoxic conditions. In this study, a significant increase in BMP values was observed after 12 days of storage (from $285 \mathrm{NmL}_{\mathrm{CH} 4} / \mathrm{g}-\mathrm{VS}_{\text {added }}$ for unstored $\mathrm{FW}$ to $639 \mathrm{NmL}_{\mathrm{CH} 4} / \mathrm{g}-\mathrm{VS}_{\text {added }}$ ). However, results showed that during the first week of storage BMP values were very unstable. Another work, performed by Fisgativa et al. [18], studied the effect of FW storage on the performance of a pilot-scale solid-state anaerobic digester $(10 \mathrm{~L})$ with leachate recirculation. Results showed that when using FW stored during 2 days before $\mathrm{AD}$, the process was completely inhibited after 4 days of digestion. After 2 weeks of inhibition, the anaerobic digestion started over again without any external intervention.

These results demonstrate that FW storage influences AD performance. However, no clear correlation between physical-chemical characteristics of the stored FW and methane production were highlighted. The aim of this work was thus to study the variations of physical structure (i.e. density) and chemical characteristics of FW during storage to better understand the degradation mechanisms that could influence the performance of FW anaerobic digestion afterwards.

\section{Materials and Methods}

Variation of food waste characteristics during storage was studied during two weeks at two different scales to mimic the storage practices of different FW producers. For practical reasons, each scale was studied independently and two different trials were set-up.

\section{Trial 1}

First trial aimed at reproducing storage conditions at household scale (small-scale), with a door-to-door collection system.

The experimental device, developed by Portejoie et al. [19], consists in six independent storage cells of $10 \mathrm{~L}$ where ambient air was evenly flushed on top (Fig. 1). Before entering one of the six cells (denoted 2 in Fig. 1), ambient air is humidified with a water trap (1) to avoid unnatural and excessive water evaporation of the sample. Inside the cell, gaseous emissions due to sample degradation are captured in the air. When exiting the cell, the air passes through an acid solution ((3)-50 mL of $2 \mathrm{~N}$ sulfuric acid) where ammonia compounds are trapped. Then, the air is dried with a silica gel column (4) and its volume recorded with a gas meter (5). Finally, the flow rate is controlled (6) before leaving the system through the pump (7). Periodically, some air is automatically sampled between the cell (2) and the ammonia trap (3) and analyzed for $\mathrm{CO}_{2}, \mathrm{~N}_{2} \mathrm{O}$ and $\mathrm{CH}_{4}$ contents with combined infrared and photoacoustic gas analyzer (INNOVA 1412). Every two days, acid traps were replaced with fresh $\mathrm{H}_{2} \mathrm{SO}_{4}$ and ammonia content was measured.
Fig. 1 Schematic diagram of the experimental device used to reproduce storage conditions. 1-Distilled water; 2-Storage cell; 3-Trapping solution; 4Silica gel column; 5-Gas meter; 6-Air flow meter; 7-Pump [19]

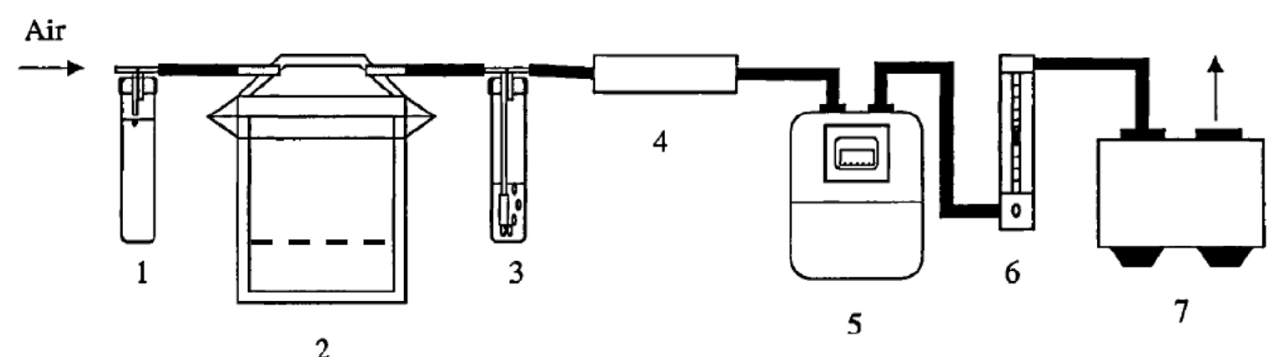

2 
For the experiment purpose, $3 \mathrm{~kg}$ of fresh FW sampled in a collective restaurant were loaded in each of the six cells without any pretreatment. A grid, placed at the bottom of the cell, efficiently separated the solid FW from the leaching liquid that was produced during the two weeks storage period. Every two or three days, one cell was stopped to perform the physical-chemical analysis. The atmospheric conditions of the experimental room were recorded all along the experiment to control the effect of temperature on FW degradation.

\section{Trial 2}

Second trial consisted in a scale-up of the first experiment to mimic the bring point and civic amenity sites collection models, where the amount of stored FW is much higher than in the door-to-door model. For this part, two large-scale reactors $(300 \mathrm{~L})$ were filled with about $150 \mathrm{~kg}$ of mixed FW from four different producers: 3 canteens (1 school, 2 traditional restaurants) and a central kitchen that provides food for several school restaurants. Compared to the $10 \mathrm{~L}$-cells used during the first trial, the $300 \mathrm{~L}$-cells had, proportionally, a smaller compartment dedicated to the storage of the leaching liquid. Thus, when necessary, the liquid phases of the large-scale trials were unloaded over the course of the experiment to avoid possible mixing of the different fractions. Physical-chemical analyses of the liquid were performed after its discharge. The solid fractions, on the other hand, remained in the two storage cells until the end of the experiment to avoid process disturbance. Physical-chemical analyses were done only at the final stage of the storage period. In addition to atmospheric conditions of the experimental room, the temperature inside the $300 \mathrm{~L}$-cells was recorded. The gaseous phase was analyzed with the INNOVA 1412 with an additional filter that also allowed the detection of ethanol while $\mathrm{N}_{2} \mathrm{O}$ emissions were not recorded during this trial.

As the trials 1 and 2 were not performed at the same period of the year and with the same FW, three additional $10 \mathrm{~L}$-cells were conducted in parallel to trial 2 as a control to compare the influence of FW type on storage performances. In this case, all reactors were stopped at the end of the experiment and physical-chemical analyses were only done at this time.

\section{Density Measurements}

For each storage cell, the height between the grid and the top of the reactor was measured and denoted $h_{t o t}$. At the beginning and at the end of the storage period, the height $h_{i}$ between the top surface of the waste and the top of the reactor was measured in four different points: one in the middle of FW's surface and three in the border of FW's surface that were spaced $120^{\circ}$ apart. The average height was calculated and denoted $\overline{h_{i}}$. The density of one sample was then calculated as follow:

$d=\frac{m}{\pi \times r^{2} \times\left(h_{t o t}-\overline{h_{i}}\right)}$

where, $d$ is the density of the sample $(\mathrm{kg} / \mathrm{L}) ; m$ is the mass of FW $(\mathrm{kg})$ at the beginning or the end of the storage period; $r$ is the cell's radius (dm); $h_{t o t}$ is the height between the grid and the top of the cell (dm); $h_{i}$ is the average height between FW's surface and the top of the cell (dm).

\section{Biomethane Potential Measurements}

The biochemical methane potential (BMP) of samples were measured in triplicate using hermetically closed $572 \mathrm{~mL}$-bottles. Each replicate was filled with inoculum, water and $3-5 \mathrm{~g}$ of ground sample $(2 \mathrm{~mm})$ to reach a total volume of $140 \mathrm{~mL}$ and an inoculum to substrate ratio 1:1 of volatile solid (VS) content. The inoculum was obtained from a well-established anaerobic pilot digester $(87 \mathrm{~L})$ acclimated to degrade pig slurry supplemented with horse feed. Before their incubation at $38{ }^{\circ} \mathrm{C}$ for 40 days, bottles were flushed with $\mathrm{N}_{2}$ to ensure anaerobic conditions. Internal pressure of bottles was measured daily to quantify biogas production. This biogas was periodically sampled to determine methane content by gas chromatography.

To avoid possible measurement variation due to inoculum differences, each grounded sample was stored at $-20{ }^{\circ} \mathrm{C}$ prior to BMP test and all BMP measurement were performed at the same time. Freezing can affect BMP values. However, because all samples were prepared following the same method, the possible artifact is equally transmitted to samples, making the comparison between samples possible. Moreover, this method was already tested on FW [20] and showed consistent results compared to the average BMP values of $460 \mathrm{~L} / \mathrm{kg}_{\mathrm{VS}}$ calculated worldwide [21].

\section{Analytical Methods}

Total solids (TS) and volatile solids (VS) were measured using standard methods [22]. TKN and total ammonia nitrogen concentrations were determined by distillation (TKN after mineralization) on wet and grounded samples [23]. Total carbon of solids was measured on finely ground dried samples by elemental analysis according to the manufacturer's instructions (Thermoflash 2000, Thermoscientific $\left({ }^{\circledR}\right)$. On liquid samples, total carbon was measured on 
Table 1 General chemical characterization of initial FW

\begin{tabular}{lllllllll}
\hline Substrate & $\mathrm{pH}$ & $\mathrm{TS}\left(\mathrm{g} / \mathrm{kg}_{\mathrm{ww}}\right)$ & $\mathrm{VS}\left(\mathrm{g} / \mathrm{kg}_{\mathrm{ww}}\right)$ & $\mathrm{TC}\left(\mathrm{gC} / \mathrm{kg}_{\mathrm{ww}}\right)$ & $\mathrm{NH}_{4}\left(\mathrm{gN} / \mathrm{kg}_{\mathrm{ww}}\right)$ & $\mathrm{TKN}\left(\mathrm{gN} / \mathrm{kg}_{\mathrm{ww}}\right)$ & $\left.\mathrm{BMP}_{(\mathrm{N}} \mathrm{L} / \mathrm{kg}_{\mathrm{ww}}\right)$ & $\mathrm{Density}(\mathrm{kg} / \mathrm{L})$ \\
\hline $\mathrm{FW}_{1}$ & 4.69 & $178 \pm 18$ & 153 & $90.2 \pm 0.9$ & $0.04 \pm 0.00$ & $4.5 \pm 0.5$ & $62 \pm 1$ & 0.717 \\
$\mathrm{FW}_{2}$ & 4.91 & $170 \pm 14$ & 138 & $78.6 \pm 2.3$ & $0.05 \pm 0.01$ & $5.7 \pm 0.2$ & $57 \pm 4$ & 0.771 \\
\hline
\end{tabular}

$F W_{l}$ Food Waste of the first trial

$F W_{2}$ Food Waste of the second trial

the raw material using a Shimadzu TOC-L analyzer following the manufacturer's instructions. The volatile fatty acid (VFA) contents and assimilated (acetate, propionate, butyrate, isobutyrate, isovalerate, lactate and succinate) of the liquids were analyzed by high performance liquid chromatography (HPLC) [24]. The average values of initial FW physical-chemical characteristics are given in Table 1.

\section{Calculation of Hydrolyzed Nitrogen Accumulation}

The accumulation of hydrolyzed nitrogen gives useful information about protein hydrolysis during storage. It was calculated according to the following equation:

$\% N_{\text {hydrolyzed }}=\frac{\left[\mathrm{NH}_{3}\right]_{t}-\left[\mathrm{NH}_{3}\right]_{t 0}}{\left[\mathrm{NH}_{3}\right]_{i}}$

where, $\left[\mathrm{NH}_{3}\right]_{t}$ is the amount of ammonia at a defined period of storage; $\left[\mathrm{NH}_{3}\right]_{t 0}$ is the amount of ammonia initially present in the fraction considered (equals to $\left[\mathrm{NH}_{3}\right]_{i}$ for the solid fraction and 0 for the liquid fraction); $\left[\mathrm{NH}_{3}\right]_{i}$ is the total nitrogen content initially loaded in the reactor cell.

\section{Statistical Method}

Analysis of variance (ANOVA) method was used to set the significance of physical-chemical variations along experiments. In this test, the null hypothesis $\mathrm{H}_{0}$ is that all sample means are equal and the alternative hypothesis is that at least one mean is different. If the probability value (p-value) of $\mathrm{H}_{0}$ is less than 0.05 , the samples are considered as significantly different. That $p$-value depends on the degree of freedom between and within samples. The degree of freedom between groups of samples (i.e. number of samples assessed minus one) is denoted Df1 and the degree of freedom within groups of samples (i.e. total number of values measured minus the number of samples) is denoted Df2. The results of ANOVA are presented between brackets in the results section using the following annotation: $F(D f 1, D f 2)=F-v a l u e, p<0.05$.
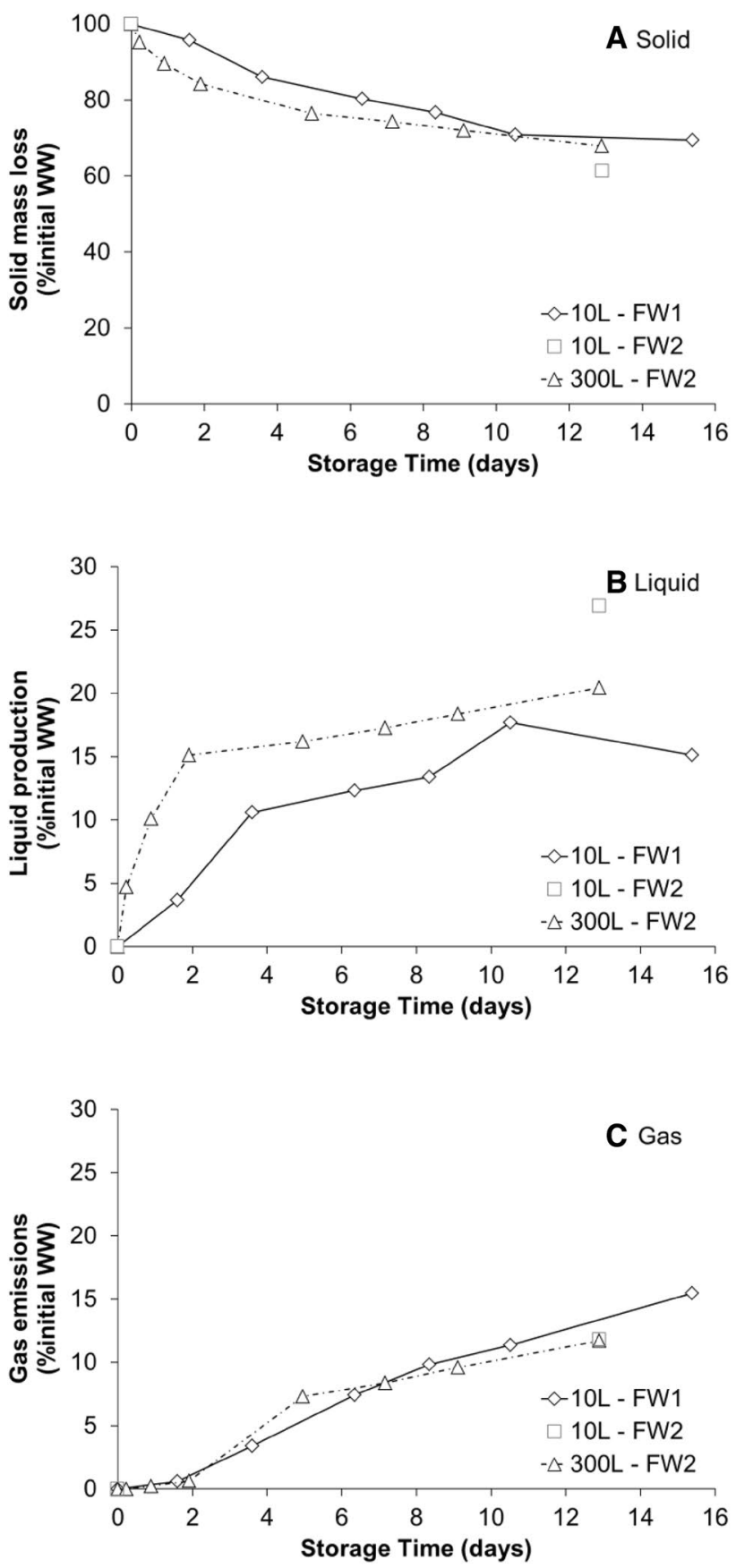

Fig. 2 Dynamic evolution of gas emissions (A), liquid production (B) and solid loss $(\mathbf{C})$ during FW storage 


\section{Results and Discussion}

\section{Physical Variations}

During storage, the physical structure of FW changed from a completely solid product (wet but without free water) to a three-phase one, with the production of liquid and gaseous fractions. Depending on the experiment, between 31 and $39 \%$ of the initial solid mass was transformed into liquid and gas, and was potentially lost (Fig. 2A).

The degradation of FW started with a rapid liquefaction of the substrate during the first days of storage (Fig. 2B). In the first trial $\left(10 \mathrm{~L}-\mathrm{FW}_{1}\right), 10 \%$ of the initial FW mass was transformed into liquid within the first 3 days of storage and only $5 \%$ during the rest of the experiment. The increase of liquid proportion at day 10 was probably due to the heterogeneity of the substrate. Indeed, in trial 1, cells were loaded with FW from the same initial pool but, due to the normal heterogeneity of FW, the substrate loaded can slightly differ from one cell to the others, leading to different degradation behaviors. In the case of the large-scale storage method $\left(300 \mathrm{~L}-\mathrm{FW}_{2}\right)$, the rapid liquefaction occurred within the first two days, where $15 \%$ of the initial mass became liquid, while only $5 \%$ more was transformed until the end of the storage. The dynamic liquid production of the control $\left(10 \mathrm{~L}-\mathrm{FW}_{2}\right.$ ) cannot be discussed as it was not monitored along the experiment. However, it showed a much higher total liquid production than the two other trials with a total of $27 \%$ of the initial FW mass transformed compared to 15 and $20 \%$ for the $10 \mathrm{~L}-\mathrm{FW}_{1}$ and the $300 \mathrm{~L}-\mathrm{FW}_{2}$ experiments, respectively (Table 2). These results show that FW degradation depends on both FW characteristics and collection system.

The rest of the total mass loss was assumed to be due to gaseous emissions. These assumed losses through gaseous emissions significantly started after two days of storage, i.e. after the rapid liquefaction step (Fig. 2C). Between day 0 and $2,0.6$ and $0.7 \%$ of the initial substrate mass was lost as gases in the small scale (10 L-FW1) and the large scale (300 L$\mathrm{FW}_{2}$ ) storage, respectively. These gaseous losses attained 15 and $12 \%$ at the end of the experiment. The total gaseous emissions of the control $\left(10 \mathrm{~L}-\mathrm{FW}_{2}\right)$ were equivalent to the

Table 2 Distribution of initial FW mass among solid, liquid and gas fractions after a 2 weeks storage period

\begin{tabular}{llll}
\hline Trial & \% Gas & \% Solid & \% Liquid \\
\hline $10 \mathrm{~L}-\mathrm{FW}_{1}$ & 15.5 & 69.4 & 15.1 \\
$10 \mathrm{~L}-\mathrm{FW}_{2}$ & 11.8 & 61.3 & 26.9 \\
$300 \mathrm{~L}-\mathrm{FW}_{2}$ & 11.7 & 67.9 & 20.4 \\
\hline
\end{tabular}

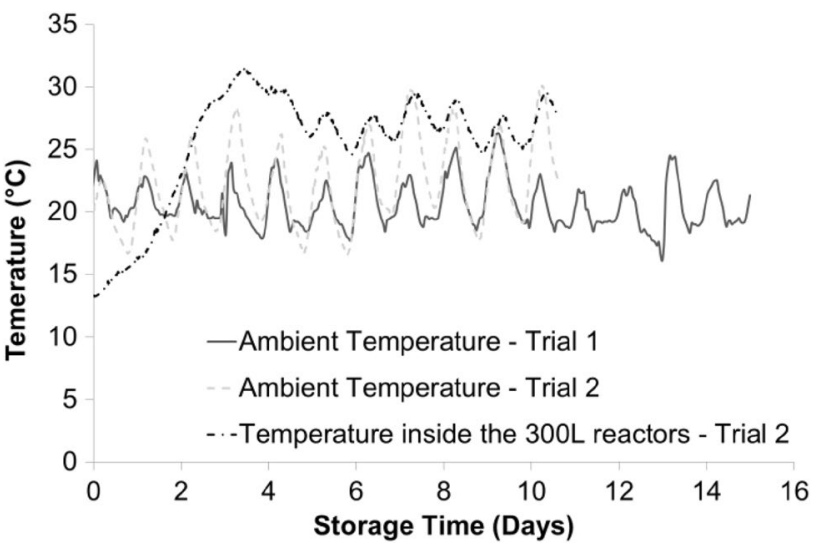

Fig. 3 Temperature variations of large scale reactors and ambient air during storage

large-scale ones, with a recorded proportion of $12 \%$ at the end of the experiment.

The temperature of the substrate inside the large scale reactors progressively increased during the first 3 days of the experiment (Fig. 3), starting at $13{ }^{\circ} \mathrm{C}$ and increasing until $32{ }^{\circ} \mathrm{C}$. After having peaked, the temperature slightly decreased and stabilized at $27 \pm 1.3{ }^{\circ} \mathrm{C}$ after day 5 , while the ambient temperature was about $22 \pm 3.3^{\circ} \mathrm{C}$. This raise in temperature is typically observed during the first stages of composting and is directly linked to the microbial activity and degradation of rapidly biodegradable compounds [25, 26]. The temperature increase also correlates with the rapid liquefaction of FW. This latter is thus probably due to the degradation of the rapidly biodegradable fraction of FW during the first 2-3 days of storage and the growth of aerobic microorganisms. The temperature inside the small-scale reactors was not measured. However, considering the volume occupied by the FW at small-scale compared to largescale (about $4.5 \mathrm{~L}$ and $177 \mathrm{~L}$, respectively), it is assumed that the temperature of FW inside the $10 \mathrm{~L}$-cells follows the ambient air temperature variations.

Density of the FW did not show the same trend of variation in the two trials and was affected by the size of the reactors. No significant change in density was observed during the storage at small-scales: the initial densities of trials 1 and 2 were 0.717 and $0.771 \mathrm{~kg} / \mathrm{L}$ respectively and the final ones were 0.658 and $0.770 \mathrm{~kg} / \mathrm{L}$ (Table 4). Conversely, at largescale the density of the substrate almost doubled, starting at 0.771 and ending at $1.340 \mathrm{~kg} / \mathrm{L}$. This difference is probably due to the weight of the large-scale FW pile combined with the leaching phenomena that must have weakened the physical structure of $\mathrm{FW}$, leading to the compaction of the substrate. 

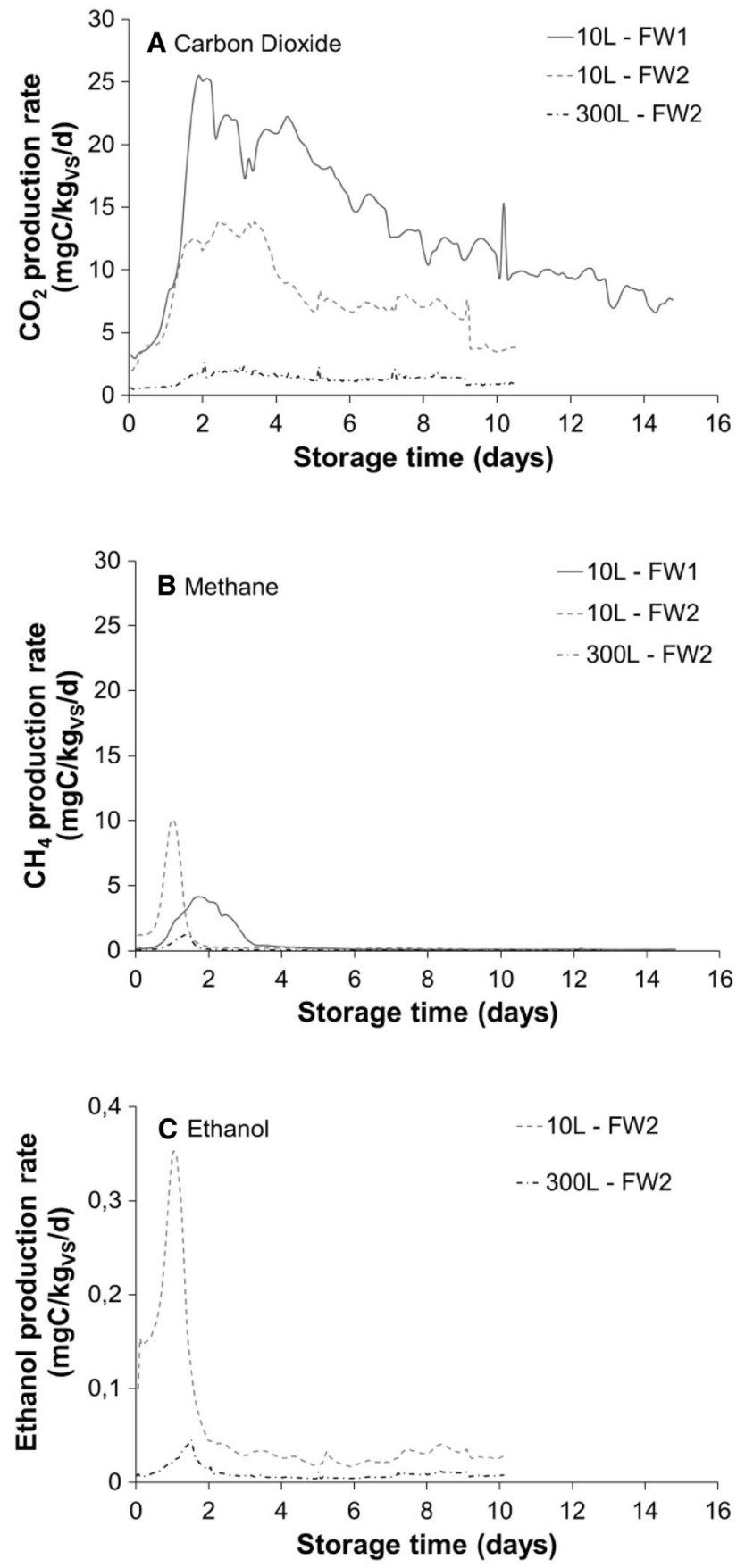

Fig. 4 Evolution of gaseous emissions composition during FW storage

\section{Gaseous Emissions}

Three main carbon-based compounds were detected during the storage: carbon dioxide, methane and ethanol.

In the first trial (10 L-FW1), a peak of methane was observed between day 1 and day 3 with a maximum methane production rate of $4.1 \mathrm{mgC} / \mathrm{kg}_{\mathrm{VS}} / \mathrm{d}$ on day 2 (Fig. 4B). After that, the production of methane was steady and close to $0.1 \mathrm{mgC} / \mathrm{kg}_{\mathrm{vs}} / \mathrm{d}$. While methane emission was very punctual, $\mathrm{CO}_{2}$ emissions were observed all along the experiment. During the first day, $\mathrm{CO}_{2}$ production rate was about $3.8 \mathrm{mgC} / \mathrm{kg}_{\mathrm{vS}} / \mathrm{d}$ and rapidly increased to reach a maximum value of $25.5 \mathrm{mgC} / \mathrm{kg}_{\mathrm{vs}} / \mathrm{d}$ at day 2 . Then the production rate progressively decreased until the end of the experiment to reach a value of $7.6 \mathrm{mgC} / \mathrm{kg}_{\mathrm{vS}} / \mathrm{d}$ (Fig. 4A). This behavior typically indicates strong aerobic microbial activity: the exponential increase of carbon dioxide production rate during the first days corresponds to the degradation of the easily biodegradable fraction of the substrate and to the aerobic growth of microorganism. Then the production rate of carbon dioxide decreases proportionally to the degradability of the remaining organic matter and environmental conditions (i.e. temperature and moisture). This emission trend thus confirms that storage occurs under aerobic and anoxic conditions.

For the two scales of trial 2, peaks of methane and ethanol were observed simultaneously at the beginning of storage (Fig. 4B, C). At its maximum (day 1), methane production rate was about 10.1 and $1.2 \mathrm{mgC} / \mathrm{kg}_{\mathrm{vs}} / \mathrm{d}$ for the small and the large scale, respectively, while ethanol production rate was about 0.35 and $0.05 \mathrm{mgC} / \mathrm{kg}_{\mathrm{VS}} / \mathrm{d}$, respectively. After day 2 , each production rate decreased down to values lower than $0.1 \mathrm{mgC} / \mathrm{kg}_{\mathrm{vs}} / \mathrm{d}$. Compared to methane and ethanol, carbon dioxide production was quite low during the first day of storage with an average production rate of 3.7 and $0.6 \mathrm{mgC} / \mathrm{kg}_{\mathrm{VS}} / \mathrm{d}$ for the small and the large scale, respectively (Fig. 4A). During the second day of storage, $\mathrm{CO}_{2}$ production rate rapidly increased to reach 13.9 and $1.9 \mathrm{mgC} /$ $\mathrm{kg}_{\mathrm{vS}} / \mathrm{d}$ at day 3. Similarly to the first trial, after the initial rapid increase the carbon dioxide production rate slowly decreased to reach 3.8 and $0.9 \mathrm{mgC} / \mathrm{kg}_{\mathrm{vS}} / \mathrm{d}$ at day 10 . Gaseous emissions profiles of trial 2 were not recorded after 10 days because of power shut down during the week-end. However it is assumed that the gas concentration did not peak during the last 4 days of storage.

The carbon dioxide production rate profiles confirm the first observations done on the physical evolution. Indeed, the raise in internal temperature of the large scale reactor follows the raise of carbon dioxide content which is also directly linked to the microbial activity inside the substrate. However, it was also found that the ratio of emitted gases par kg of organic matter initially put in the storage cell was lower at large-scale compared to small-scale pilot. Such deviation could be due to differences in specific exchange surfaces applied in each scale. The specific exchange surface is calculated as the ratio between the top surface of FW that is in contact with the air flushed in the storage cell and the volume of FW initially introduced in the cell. Then, the large-scale cell has much lower specific exchange surface than the small-scale with a value of $2.1 \mathrm{~m}^{2} / \mathrm{m}^{3}{ }_{\mathrm{FW}}$ compared to $29.5 \mathrm{~m}^{2} / \mathrm{m}^{3} \mathrm{FW}$, respectively. This means that in the 
Table 3 Amount of initial carbon transformed into gaseous ethanol, carbon dioxide and methane during storage

\begin{tabular}{|c|c|c|c|c|c|c|c|}
\hline \multirow[t]{2}{*}{ Trial } & \multirow[t]{2}{*}{$\begin{array}{l}\text { Initial C con- } \\
\text { tent }\left(\mathrm{gC} / \mathrm{kg}_{\mathrm{ww}}\right)\end{array}$} & \multirow{2}{*}{$\begin{array}{l}\text { Loss as } \\
\mathrm{C}_{2} \mathrm{H}_{5} \mathrm{OH}(\mathrm{gC} / \\
\left.\mathrm{kg}_{\mathrm{ww}}\right)\end{array}$} & \multirow[t]{2}{*}{$\begin{array}{l}\text { Loss as } \\
\mathrm{CO}_{2}\left(\mathrm{gC} \mathrm{kg}_{\mathrm{ww}}\right)\end{array}$} & \multirow[t]{2}{*}{$\begin{array}{l}\text { Loss as } \mathrm{CH}_{4}(\mathrm{gCl} \\
\left.\mathrm{kg}_{\mathrm{ww}}\right)\end{array}$} & \multicolumn{2}{|c|}{$\begin{array}{l}\text { Total C losses through } \\
\text { gases }\end{array}$} & \multirow{2}{*}{$\begin{array}{l}\text { Initial mass loss } \\
\text { through C-gases } \\
\left(\% \mathrm{~m}_{\mathrm{i}}\right)\end{array}$} \\
\hline & & & & & $\left(\mathrm{gC} / \mathrm{kg}_{\mathrm{ww}}\right)$ & $\left(\% \mathrm{C}_{\text {initial }}\right)$ & \\
\hline $10 \mathrm{~L}-\mathrm{FW} 1$ & 90.2 & $-^{\mathrm{a}}$ & 1.9 & 0.2 & 2.1 & 2.3 & 0.9 \\
\hline $10 \mathrm{~L}-\mathrm{FW}_{2}$ & 78.6 & $<0.1$ & 1.2 & 0.1 & 1.4 & 1.7 & 0.6 \\
\hline $300 \mathrm{~L}-\mathrm{FW}_{2}$ & 78.6 & $<0.1$ & 0.5 & $<0.1$ & 0.5 & 0.7 & 0.3 \\
\hline
\end{tabular}

${ }^{\mathrm{a} N o t}$ determined

large-scale pilot the air, and as a consequence oxygen, available in the middle or at the bottom of the FW pile is limited which may lower the degradation of FW.

The presence of methane during the first two days of storage shows that anaerobic conditions settled inside storage cell for a short interval. With anaerobic conditions, an alcoholic fermentation also started inside the storage cells and led to the production of ethanol with the degradation of easily degradable sugars present in FW [27]. Since air was continuously flushed in the reactors aerobic conditions may have settled back allowing the growing of aerobic microorganisms and the production of carbon dioxide.

The overall carbon content lost by gaseous emissions was calculated and is summarized in Table 3. Depending on the experiment, the amount of volatilized carbon ranged from 0.5 to $2.1 \mathrm{gC} / \mathrm{kg}_{\mathrm{ww}}$ with the lowest value found for the largescale pilot. These values are very low compared to those usually measured on manure for the same storage period (42.5 $\mathrm{gC} / \mathrm{kg}_{\mathrm{WW}}$ [28]) and represent about 0.7 and $2.3 \%$ of carbon initially introduced in the storage cell. According to these results, most of the initial carbon present in FW remained in the liquid or solid fraction of the substrate after two weeks of storage, and should be available for a possible anaerobic digestion process. It also means that the mass losses that were considered to be due to gaseous emissions (Fig. 2C) are composed of other components than carbonaceous gases, as water. For the trial " $10 \mathrm{~L}-\mathrm{FW} 1$ " for example, $15.5 \%$ of the total solid mass was lost as gases and from these $15.5 \%$, only $0.9 \%$ of the total solid mass were emitted as carbon-based compounds.

The nitrogen-based emissions, such as ammonia and nitrous oxide, were also monitored during the storage period in Trial 1. However, nitrogen was only found as traces of ammonia in acid traps without any $\mathrm{N}_{2} \mathrm{O}$ emissions detected, which was thus not analyzed in Trial 2.The total nitrogen content loss was below $0.02 \mathrm{mgN}$ during the entire storage period, regardless to the considered trial, proving that it can be neglected.

The assessment of gaseous emissions during FW storage highlighted the start of organic matter degradation through aerobic and anoxic conditions. In the following part, chemical evolution of the solid and liquid phases will be discussed to better understand the mechanisms of organic matter change during storage.

\section{Chemical Variations}

\section{Solid Phase}

Variations of total solid amounts contained in the solid fraction are presented in Fig. 5A. In the first trial (10 L-FW1) TS amount drastically decreased during the first week of storage and stabilized during the second week. At the end of storage, about $34 \mathrm{w} \%$ (w\% $=\%$ of the initial wet weight) of the initial TS introduced in the reactor was lost. Similar behavior was observed for VS amount variations (data not shown) with a final VS loss of $33 \mathrm{w} \%$. In the second trial and at small scale $\left(10 \mathrm{~L}-\mathrm{FW}_{2}\right)$, the proportion of TS and VS losses were equivalent to the first trial with values of 32 and $30 \mathrm{w} \%$, respectively. As a negligible part of carbon was transformed into gases (cf. results on gaseous emissions), it was assumed that the lost TS and VS amounts were transferred in the liquid fraction. At large-scale (300 $\left.\mathrm{L}-\mathrm{FW}_{2}\right)$, about 21 and $23 \mathrm{w} \%$ of the initial TS and VS were lost, respectively, which is less than results observed at smallscale. This shows a limited hydrolysis performance probably due to the limited aerobic activity at large-scale (compared to small-scale) as it was previously demonstrated with gaseous emissions results.

Nevertheless, no significant differences in TS contents were observed neither over the course of the experiments nor at the end of the storage periods at small-scale with average values and standard deviations of $169 \pm 10 \mathrm{~g} / \mathrm{kg}_{\mathrm{ww}}$ for $\mathrm{FW}_{1}$ and $178 \pm 11 \mathrm{~g} / \mathrm{kg}_{\mathrm{ww}}$ for $\mathrm{FW}_{2}$ (Fig. 5B). It means that for each experiment, the ratio between the total mass loss that contains both water and total solid (Fig. 2A) and TS amount loss (Fig. 5A) kept constant over the course of the experiment. At large-scale, on the other hand, storage significantly affected TS content $(\mathrm{F}(1,7)=11.41, \mathrm{p}<0.05)$ and a raise in TS content value was observed from $170 \mathrm{~g} /$ $\mathrm{kg}_{\mathrm{ww}}$ at the beginning of the experiment to $192 \mathrm{~g} / \mathrm{kg}_{\mathrm{ww}}$ after 15 days of storage (Tables 1,4$)$. In this case, the total mass loss recorded (32 w\%) was much higher than the sole TS loss $(21 \mathrm{w} \%)$ traducing a high loss of water and leading to an 

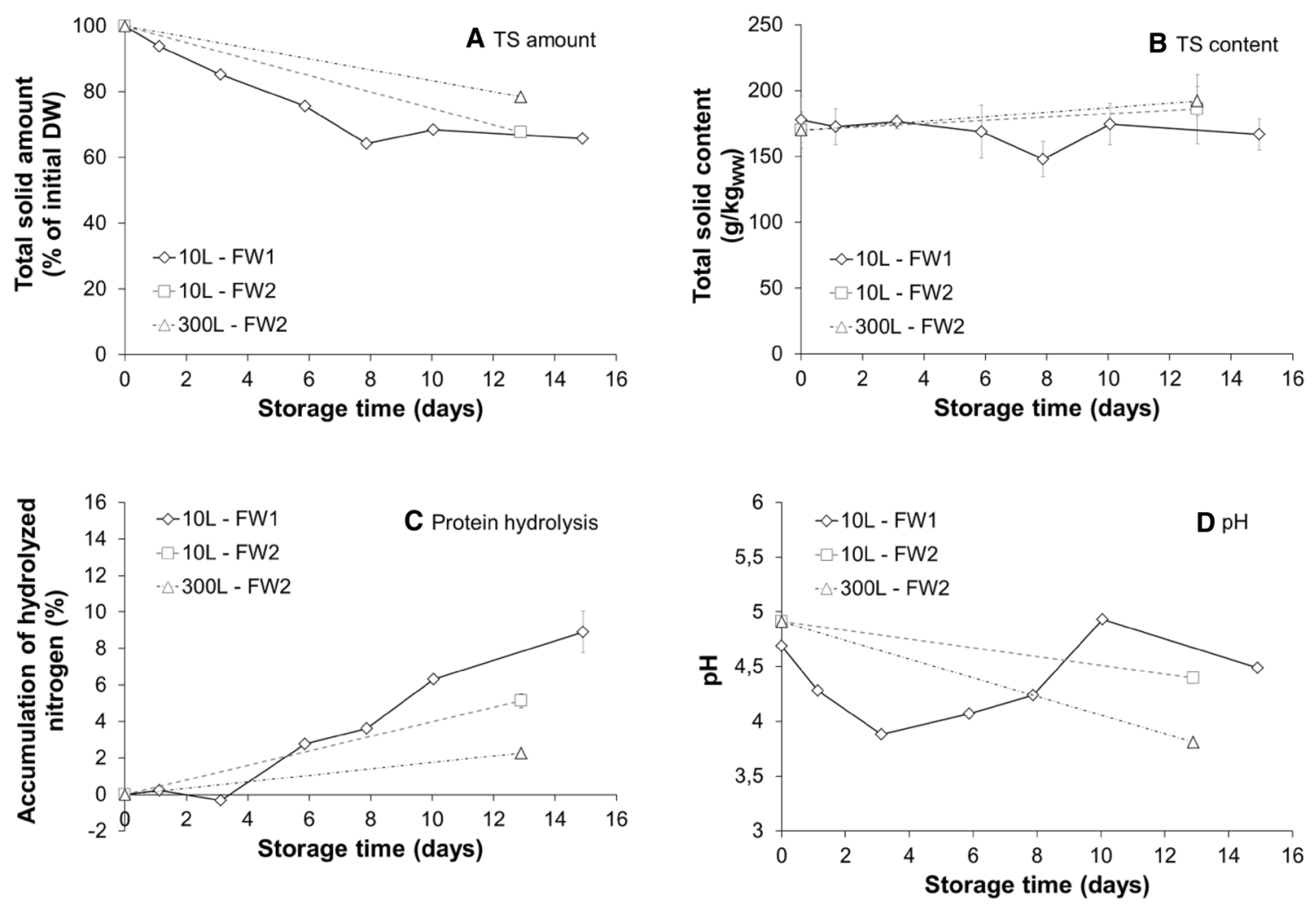

Fig. 5 Evolution of TS content (A), VS amount $(\mathbf{B})$, protein hydrolysis $(\mathbf{C})$ and $\mathrm{pH}(\mathbf{D})$ of the solid fraction during FW storage

Table 4 Solid fraction characteristics of FW after two weeks of storage

\begin{tabular}{llllllll}
\hline Trial & $\mathrm{pH}$ & $\mathrm{TS}\left(\mathrm{g} / \mathrm{kg}_{\mathrm{ww}}\right)$ & $\mathrm{VS}\left(\mathrm{g} / \mathrm{kg}_{\mathrm{ww}}\right)$ & $\mathrm{TC}\left(\mathrm{gC} / \mathrm{kg}_{\mathrm{ww}}\right)$ & $\mathrm{NH}_{4}\left(\mathrm{gN} / \mathrm{kg}_{\mathrm{ww}}\right)$ & $\mathrm{BMP}\left({ }_{\mathrm{N}} \mathrm{L} / \mathrm{kg} \mathrm{ww}_{\mathrm{ww}}\right)$ & $\mathrm{Density}(\mathrm{kg} / \mathrm{L})$ \\
\hline $10 \mathrm{~L}-\mathrm{FW} 1$ & 4.50 & $167 \pm 12$ & 146 & $83.1 \pm 1.0$ & $0.69 \pm 0.17$ & $59 \pm 3$ & 0.658 \\
$10 \mathrm{~L}-\mathrm{FW}_{2}$ & 4.40 & $186 \pm 26$ & 165 & $91.2 \pm 10.0$ & $0.55 \pm 0.07$ & $71 \pm 4$ & 0.770 \\
$300 \mathrm{~L}-\mathrm{FW}_{2}$ & 3.81 & $192 \pm 11$ & 167 & $91.2 \pm 2.5$ & $0.26 \pm 0.03$ & $77 \pm 8$ & 1.340 \\
\hline
\end{tabular}

increase of TS content. This drying of the solid phase is in agreement with a higher temperature increase and a higher compaction. In the same way, even though VS amounts decreased over the course of the experiment, instantaneous VS concentration did not significantly varied during storage and remained constant at small and large-scale. The average values and standard deviations were $148 \pm 9,157 \pm 11$ and $159 \pm 12 \mathrm{~g} / \mathrm{kg}_{\mathrm{ww}}$ for trials $10 \mathrm{~L}-\mathrm{FW} 1,10 \mathrm{~L}-\mathrm{FW}_{2}$ and $300 \mathrm{~L}-\mathrm{FW}_{2}$, respectively. Lü et al. [17] observed different results when studying FW storage. After 12 days, TS and VS contents were significantly higher than at the beginning of the experiment with respective values of 241.3 and $212.9 \mathrm{~g} / \mathrm{kg}_{\mathrm{ww}}$ initially and 281.5 and $249.0 \mathrm{~g} / \mathrm{kg}_{\mathrm{ww}}$ at the end of the experiment. In their experiment, the combination of storage room temperature $\left(35^{\circ} \mathrm{C}\right)$ and the shredding of the substrate prior to storage may have eased the degradation of FW and consequently favored water evaporation and concentrating dry and organic matter. When using paper bags for
FW disposal at $22{ }^{\circ} \mathrm{C}$ and after 3 weeks of storage, Nilsson Påledal et al. [16] showed a drastic increase of TS content while it remained stable when using plastic bags. The paper bags may have facilitated water evaporation while it was not the case in plastic bags.

Ammonia content in the solid fraction of FW was also monitored for each trial as it gives useful information on the protein hydrolysis proportion during storage. The accumulation of hydrolyzed nitrogen was calculated over the course of the experiments and is given in Fig. 5C for each trial. At the beginning of the experiments, FW samples showed similar and low ammonia content with values of 0.04 and $0.05 \mathrm{gN} / \mathrm{kg}_{\mathrm{ww}}$ for $\mathrm{FW}_{1}$ and $\mathrm{FW}_{2}$, respectively. During the first three days of storage (trial 1, $10 \mathrm{~L}-\mathrm{FW} 1$ ), the accumulated proportion of hydrolyzed nitrogen remained stable and quite low with an average value of $0 \%$. After that, protein hydrolysis proportion progressively and significantly increased to reach $9 \%$. These results must be interpreted 
in the light of carbon dioxide profiles. Indeed, during the first days of storage, microbial activity was exponentially increasing (Fig. 4A) and thus microorganisms needed nitrogen to grow. The soluble nitrogen, i.e. ammonia produced with the protein hydrolysis, was then rapidly consumed by microorganisms resulting in steady ammonia content in the solid. At day 3, microbial activity reached its maximum and started to progressively decrease until the end of the experiment. Hydrolyzed nitrogen then started to accumulate in the solid as microorganisms consumed less and less soluble nitrogen showing a higher nitrogen hydrolysis proportion. At the end of the second trial, hydrolysis efficiency was about 5 and $2 \%$ for the small-scale $\left(10 \mathrm{~L}-\mathrm{FW}_{2}\right)$ and the largescale $\left(300 \mathrm{~L}-\mathrm{FW}_{2}\right)$ experiments, respectively. The lower proportion of hydrolyzed proteins in the larger scale confirms the hypothesis of limited hydrolysis of organic matter in the $300 \mathrm{~L}$-cells.

Regardless to the scale, $\mathrm{pH}$ of the solid fraction was lower than 5 during the entire storage period (Fig. 5D), which explains the absence of ammonia in the gaseous fraction. Indeed, the $\mathrm{pKa}$ of $\mathrm{NH}_{4}{ }^{+} / \mathrm{NH}_{3}$ is 9.2 and most of the ammonia content was on its soluble and acidic form $\left(\mathrm{NH}_{4}{ }^{+}\right)$at $\mathrm{pH}<5$. However, $\mathrm{pH}$ was not stable along the experiments. During the first trial, $\mathrm{pH}$ of FW started at 4.69 and decreased during the first three days to reach a value of 3.88 indicating a production of organic acids because of FW hydrolysis. During the rest of the experiment, $\mathrm{pH}$ progressively increased to reach a value of 4.49 which could be due to the consumption of the organic acids previously produced. Because of sample heterogeneity (see section 'physical variations'), the sample at day 10 was probably slightly different from the others as it showed a $\mathrm{pH}$ value much higher than the others and was not taken into account to discuss the $\mathrm{pH}$ variation dynamics. The second small-scale trial $\left(10 \mathrm{~L}-\mathrm{FW}_{2}\right)$ showed similar acidic condition at the end of the storage period than in the first experiment (10 L-FW1) with a final $\mathrm{pH}$ of 4.41. Compared with the latter, large-scale process had a much lower final $\mathrm{pH}$ value (3.81) than the two other experiments with probably more organic acid concentration after 2 weeks of storage due to a lower microbial activity.

\section{Liquid Phase}

The chemical characteristics of the liquid fractions produced during storage were also monitored all along the experiment. In the first trial (10 L-FW1), TS amount slightly increased during the first three days of storage (Fig. 6A). At day 1 , about $2 \%$ of the initial TS amount of the FW was accumulated in the liquid fraction and $3 \%$ at day 3 . From day 3 until day 8 , TS amount remained stable and finally
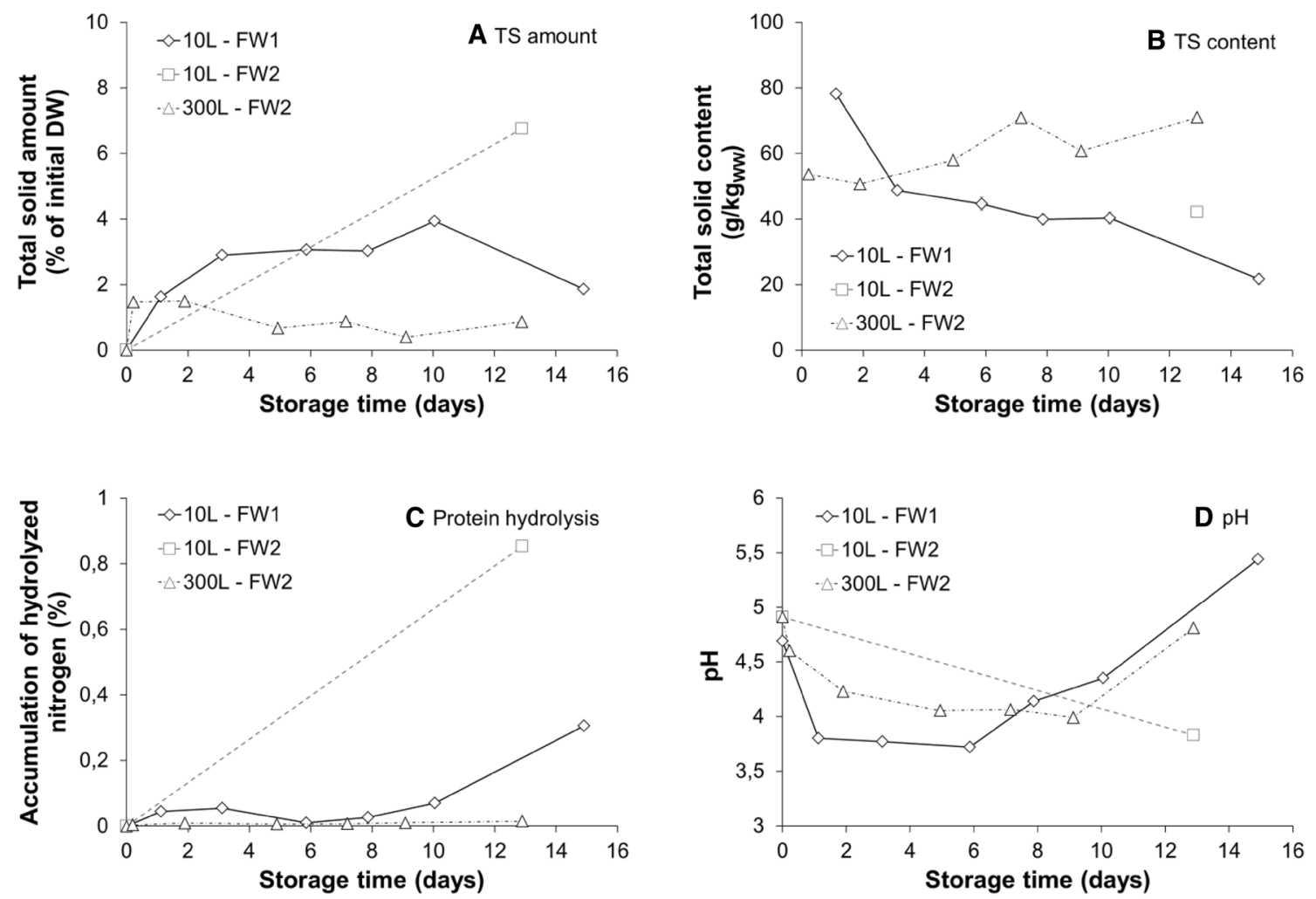

Fig. 6 Evolution of TS content (A), VS amount $(\mathbf{B})$, protein hydrolysis $(\mathbf{C})$ and $\mathrm{pH}(\mathbf{D})$ of the liquid fraction during FW storage 
dropped to $2 \%$ at the end of the experiment. VS amounts followed the same trend along the storage (data not shown). The decrease in TS and VS amounts in the liquid fraction indicates a consumption of organic matter during the second week of storage. Trial 2, on the other hand, showed different trends. At small-scale $\left(10 \mathrm{~L}-\mathrm{FW}_{2}\right)$, the final TS and VS amounts of the liquid fraction represented 7 and $8 \%$ of the initial dry weight loaded in the storage cells, respectively. These values are much higher than those recorded during the first trial, confirming that degradation of FW during storage strongly depends on the initial composition of FW. A previous work showed that geographical origin, source separation and seasonality significantly influences physical-chemical characteristics of FW [21]. Consequently, storage may differently affect physical-chemical characteristics of FW from different origins. These results cannot be compared to the large-scale values as the experimental sampling was different. Because leachate was periodically removed from the reactor at large-scale, organic matter was not subjected to possible consumption mechanisms. Indeed, the instantaneous TS amount in the liquid fraction at large-scale did not significantly varied as values ranged from 1.5 to $0.4 \%$ of the initial TS amount, and reached a final value of $0.9 \%$. This indicates that the mass of TS leaching out the storage reactor was stable along the experiment. After two weeks of storage, about $6 \%$ of the initial dry weight loaded in the storage cells leached out the solid.

In terms of concentration (Fig. 6B), TS content of the liquid fraction decreased progressively from 78 to $22 \mathrm{~g} / \mathrm{kg}_{\mathrm{ww}}$ during the first trial (10 L-FW1). As the total solid mass was stable during the first storage week, this decrease in concentration is mostly due to a dilution phenomenon because of water leaching. During the second week, the decrease in TS mass highlighted the consumption of the organic matter present in the liquid fraction that intensified the decrease in TS concentration. In the case of trial 2 and at small-scale $\left(10 \mathrm{~L}-\mathrm{FW}_{2}\right)$, the final TS content was $42 \mathrm{~g} / \mathrm{kg}_{\mathrm{ww}}$ which was higher than trial 1 confirming the importance of $\mathrm{FW}$ composition on the storage behavior.

Part of the organic matter present in the liquid fraction was composed of volatile fatty acids and assimilated, mainly acetic, propionic, malic and lactic acids. In the first trial, total VFA content progressively increased to reach $16 \mathrm{~g} /$ $\mathrm{kg}$ of initial VS (i.e. $\mathrm{g} / \mathrm{kgVS}_{\text {in }}$ ) at day 6 and then started to decrease and reached $3 \mathrm{~g} / \mathrm{kgVS}_{\text {in }}$ at the end of the experiment (Fig. 7A). The accumulation of VFA during the first week of storage confirmed the start of FW hydrolysis and acidification. In the light of VS amounts results, VFA were probably consumed by adapted microorganisms during the second week of storage. Depending on the scale, trial 2 showed very different trends with the highest VFA content recorded for the small-scale at a value of $29.4 \mathrm{~g} / \mathrm{kgVS}_{\text {in }}$ at the end of the experiment. In this case, FW hydrolysis seemed more
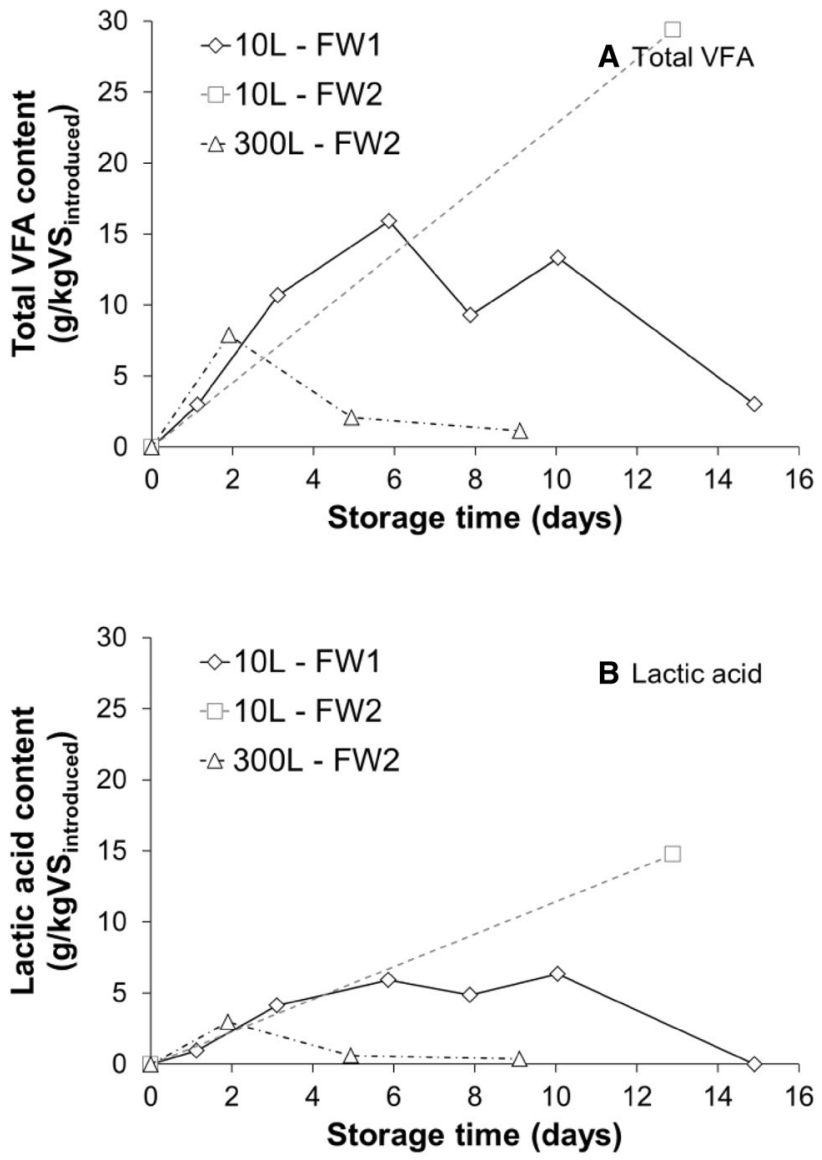

Fig. 7 Variation of VFA (A) and lactic acid (B) content in the liquid fraction based on the initial VS amount of FW introduced in storage cells

efficient than in the first trial probably because of FW initial composition. At large scale $\left(300 \mathrm{~L}-\mathrm{FW}_{2}\right)$, FW hydrolysis started similarly to the first trial $(10 \mathrm{~L}-\mathrm{FW} 1)$ until day 2 , but was rapidly stopped probably because of limited aerobic conditions that slowed down the development of hydrolytic microorganisms.

A special attention was paid to the variation of lactic acid content during storage as it is proven to be inhibitory for anaerobic digestion when reaching concentrations of $6-8 \mathrm{~g} / \mathrm{L}$ $[29,30]$. Overall, lactic acid content variations were similar to total VFA contents. The highest concentration recorded for the first trial $(10 \mathrm{~L}-\mathrm{FW} 1)$ was $5.9 \mathrm{~g} / \mathrm{kgVS}_{\text {in }}$ at day 6 , $14.8 \mathrm{~g} / \mathrm{kgVS}_{\text {in }}$ at day 13 for the experiment 2 at small-scale $\left(10 \mathrm{~L}-\mathrm{FW}_{2}\right)$ and $3.0 \mathrm{~g} / \mathrm{kgVS}_{\text {in }}$ at day 2 . The production of lactic acid during storage of FW is due to the initial presence of lactic acid bacteria (LAB) in the substrate [31] and was already reported in several studies [5, 30, 32]. This suggests that lactic acid and VFA are also present in the solid fraction of stored $\mathrm{FW}$, which is consistent with low $\mathrm{pH}$ of the solid content measured at the end of all experiments. Moreover, a comparison between the $\mathrm{pH}$ of the solid fraction, VFA 
Table 5 Liquid fraction characteristics of FW after two weeks of storage

\begin{tabular}{lllllll}
\hline Trial & $\mathrm{pH}$ & $\mathrm{TS}\left(\mathrm{g} / \mathrm{kg}_{\mathrm{ww}}\right)$ & $\mathrm{VS}\left(\mathrm{g} / \mathrm{kg}_{\mathrm{ww}}\right)$ & $\mathrm{TC}\left(\mathrm{gC} / \mathrm{kg}_{\mathrm{ww}}\right)$ & $\mathrm{NH}_{4}\left(\mathrm{gN} / \mathrm{kg}_{\mathrm{ww}}\right)$ & $\begin{array}{l}\mathrm{Total} \\
\mathrm{C} \text { loss } \\
\left(\% \mathrm{C}_{\text {initial }}\right.\end{array}$ \\
\hline $10 \mathrm{~L}-\mathrm{FW} 1$ & 5.44 & 22 & 16 & 12.6 & 0.10 & 2.3 \\
$10 \mathrm{~L}-\mathrm{FW}_{2}$ & 3.83 & 42 & 34 & 18.5 & 0.18 & 6.3 \\
$300 \mathrm{~L}-\mathrm{FW}_{2}$ & 4.81 & 71 & 63 & 3.7 & 0.13 & 0.8 \\
\hline
\end{tabular}

and lactic acid profiles in the liquid fractions indicated that the organic acids of the solid most likely followed the same trend as organic acids of the liquid fraction. Wang et al. [32] reported trends similar to what was found during the first trial for what concerns the lactic acid production during FW storage, with a maximum concentration of $19 \mathrm{~g} / \mathrm{L}$ found at day 8 considering at 2 weeks storage period. Zhao et al. [30] reported a maximum concentration of $10 \mathrm{~g} / \mathrm{L}$ after 1.5 days of storage for a total storage period of 2 days. Comparatively, raw maximum lactic acid concentration were $7.4 \mathrm{~g} / \mathrm{L}$ at day $6,7.4 \mathrm{~g} / \mathrm{L}$ at day 14 and $4.6 \mathrm{~g} / \mathrm{L}$ at day 9 for experiments $10 \mathrm{~L}-\mathrm{FW} 1,10 \mathrm{~L}-\mathrm{FW}_{2}$ and $300 \mathrm{~L}-\mathrm{FW}_{2}$, respectively. The lower range of concentration recorded is probably due to differences in pre-treatment. Indeed, Wang et al. [32] and Zhao et al. [30] worked on $500 \mathrm{~g}$ and $100 \mathrm{~g}$ of shredded FW respectively, which might have eased the organic matter degradation process compared to $\mathrm{FW}$ without shredding pretreatment (i.e. as in our study). However, the raw concentrations of lactic acid at small-scale are considered as potentially inhibitory for $\mathrm{AD}$ if the ratio substrate/inoculum is not adapted $[29,30]$.

At small-scale, the variations of VFA contents directly impacted $\mathrm{pH}$ of the liquid fractions. For the first trial $(10 \mathrm{~L}-$ FW1), $\mathrm{pH}$ rapidly dropped at day 1 with a value of $3.80 \mathrm{com}-$ pared to the initial pH of the FW that was 4.69 (Tables 4, 5). After 5 stable days, $\mathrm{pH}$ increased at day 6 when VFA content started to decrease and reached a final value of 5.44. The small-scale second trial $\left(10 \mathrm{~L}-\mathrm{FW}_{2}\right)$, had the lowest $\mathrm{pH}$ at the end of the experiment (3.83) and also the highest VFA content. On the other hand, the large-scale experiment did not show a clear correlation between $\mathrm{pH}$ and VFA content as VFA content was at its minimum level at day 9 while $\mathrm{pH}$ was also at is minimum (3.99). This was probably due to the presence of other organic acids that were not monitored in this study, such as malonic and oxalic acids that are produced during FW composting, i.e. under aerobic conditions [33]. However, at the end of the storage period, $\mathrm{pH}$ increased and reached a value of 4.81 (Table 5), indicating the probable consumption of the acidic compounds in the liquid fraction.

In terms of total carbon, the compounds included in the liquid fraction corresponded to $2.3,6.3$ and $0.8 \%$ of the carbon initially introduced in the storage cells for trial $10 \mathrm{~L}-$ FW1, trial $10 \mathrm{~L}-\mathrm{FW}_{2}$ and trail $300 \mathrm{~L}-\mathrm{FW}_{2}$, respectively (Table 5). In total (gas + liquid), the carbon loss represented 4.6, 8.0 and $1.5 \%$ of the carbon initially stored. According to these results, storage led to a carbon loss that represents less than $10 \%$ of the initial amount available for valorization, regardless of the scale and type of FW used. However, the carbon mass balance (Table 6) showed a lack of carbon recovery ranging between 18 and $30 \%$, depending on the experiment. One reason is probably correlated to the composition of FW at the end of the storage. Considering the low $\mathrm{pH}$ values recorded, it is assumed that the solid fraction contained a large amount of VFA that might have volatilized during samples drying before VS content measurement. As the VFA content of the solid was not directly measured in the solid, they were estimated according to VFA content in the liquid fraction. Results showed that VFA volatilization in the solid fraction represent about $2 \%$ of the mass balance gap. The remaining gap is partly attributed to measurements uncertainties that represent about $12 \%$ of this gap.

Accumulations of hydrolyzed nitrogen were also calculated for the liquid fraction as defined in Eq. (2). Regardless to the experiment, ammonia content was lower in the liquid fractions than in solid fractions (Tables 4,5). The proportion of accumulated hydrolyzed nitrogen (resulting from protein hydrolysis) that leached out the solid represented less than $1 \%$ (Fig. 6C). The lowest value corresponded to the largescale experiment $\left(300 \mathrm{~L}-\mathrm{FW}_{2}\right)$, with a final accumulation of hydrolyzed nitrogen less than $0.1 \%$. Such low percentage is consistent with the hypothesis of low hydrolysis efficiency of the FW at large-scale compared to small-scale. Indeed, at small-scale the accumulation of hydrolyzed nitrogen were
Table 6 Carbon distribution of the different fractions of FW after storage

\begin{tabular}{lccccc}
\hline Trial & $\begin{array}{l}\text { Initial } \mathrm{C} \text { in } \\
\mathrm{FW}(\mathrm{gC})\end{array}$ & $\begin{array}{l}\text { Final } \mathrm{C} \text { in } \\
\text { solid }(\mathrm{gC})\end{array}$ & $\begin{array}{l}\text { Final } \mathrm{C} \text { in } \\
\text { liquid }(\mathrm{gC})\end{array}$ & $\begin{array}{l}\text { Final } \mathrm{C} \text { in } \\
\text { gas }(\mathrm{gC})\end{array}$ & $\begin{array}{l}\text { Mass balance } \\
\%\end{array}$ \\
\hline $10 \mathrm{~L}-\mathrm{FW}_{1}$ & 272 & 176 & 6 & 6 & 70 \\
$10 \mathrm{~L}-\mathrm{FW}_{2}$ & 244 & 178 & 19 & 4 & 81 \\
$300 \mathrm{~L}-\mathrm{FW}_{2}$ & 11,720 & 9451 & 93 & 75 & 82 \\
\hline
\end{tabular}



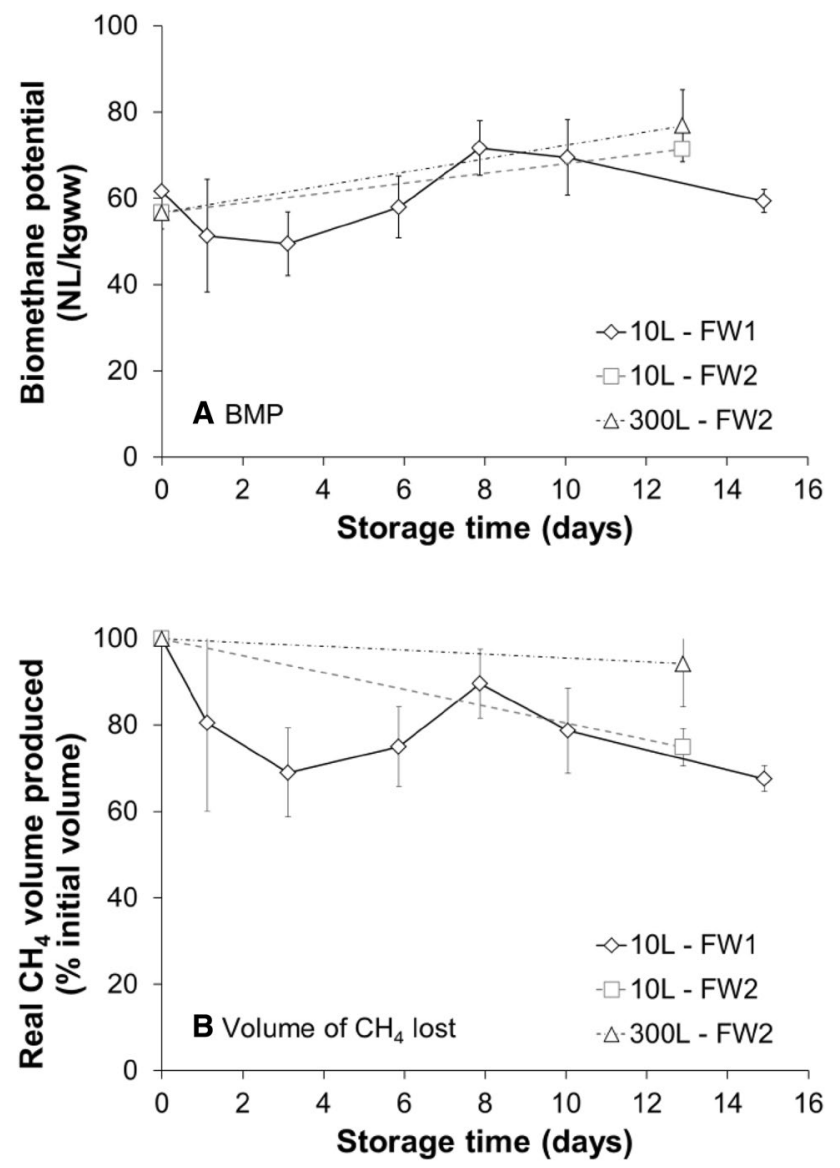

Fig. 8 Variation of A BMP during storage and $\mathbf{B}$ real volume of methane potentially produced after storage

0.3 and $0.9 \%$ for trial $1(10 \mathrm{~L}-\mathrm{FW} 1)$ and trial $2(10 \mathrm{~L}-$ $\mathrm{FW}_{2}$ ), respectively.

The chemical assessment of solid and liquid fractions showed significant differences that were correlated with the initial composition of FW or with the scale of storage. The last part of this work consisted in studying the impact of physical-chemical variations of the samples on biomethane potentials.

\section{Biomethane Potentials}

According to the previous results, the amount of organic matter in the liquid fraction after two weeks of storage represents less than $10 \%$ of the organic matter contained in the FW before storage. For this reason, BMP tests were performed only on the solid fraction of FW.

In the first trial (10 L-FW1), BMP values varied depending on the storage duration applied (Fig. 8A). Initially, $\mathrm{BMP}$ value and standard deviation of $\mathrm{FW}_{1}$ was $62 \pm 1{ }_{\mathrm{N}} \mathrm{L} /$ $\mathrm{kg}_{\mathrm{ww}}$ (Table 1). During the first 3 days, BMP significantly decreased to reach a value of $50 \pm{ }_{N} \mathrm{~L}^{\mathrm{kg}}{ }_{\mathrm{ww}}(\mathrm{F}(1,4)=82.31$, $\mathrm{p}<0.05)$ and increased again until day 8 to $72 \pm 6{ }_{N} \mathrm{~L} / \mathrm{kg}_{\mathrm{ww}}$
$(\mathrm{F}(1,4)=149.77, \mathrm{p}<0.05)$. During the last week, BMP values slowly and significantly decreased to $59 \pm 3{ }_{\mathrm{N}} \mathrm{L} / \mathrm{kg}_{\mathrm{ww}}$ $(\mathrm{F}(1,4)=129.53, \mathrm{p}<0.05)$. It can be seen that the standard deviation on BMP results varied from 2 to $26 \%$. The high values recorded are probably due to the heterogeneity of the samples inside a given storage cell. Because the mass of substrate used to perform BMP test is quite low (3-5 g), and even if samples were ground to $2 \mathrm{~mm}$, the perfect homogeneity of the sample is not guaranteed. However, the variations of standard deviations reflect how anaerobic digestion can be affected by the intrinsic heterogeneity of the substrate. On the other hand, the variations of the BMP values along storage are strongly correlated to the VFA and lactic acid contents in the liquid fraction. Indeed, between days 3 and 6 , the VFA and lactic acid contents recorded were at their highest level and corresponded to low levels of BMP. At day 8 , VFA and lactic acid contents started to decrease while BMP value was at its highest level. The methane production was probably partially inhibited by the presence of VFA and, especially, lactic acid [5, 30, 32] that are assumed to be present in the solid. During the second week, data were not correlated anymore as VFA and lactic acid contents were very low $\left(>3 \mathrm{~g} / \mathrm{kg}_{\mathrm{vS}}\right)$ and BMP did not increase as it did during the first week. According to Fig. 5B, the VS amount of the solid fraction was stable during the second week of the storage period suggesting that the decrease in BMP is not correlated to a loss of VS, probably because only the slowly biodegradable material of the FW remained at the end of the experiment. In the second trial, regardless to the scale, BMP values significantly increased during storage starting at $57 \pm 4{ }_{N} \mathrm{~L} / \mathrm{kg}_{\mathrm{ww}}$ and ending at $71 \pm 4{ }_{\mathrm{N}} \mathrm{L} / \mathrm{kg}_{\mathrm{ww}}$ and $77 \pm 8{ }_{\mathrm{N}} \mathrm{L} /$ $\mathrm{kg}_{\mathrm{ww}}$ at small $\left(10 \mathrm{~L}-\mathrm{FW}_{2}\right)$ and large-scale $\left(300 \mathrm{~L}-\mathrm{FW}_{2}\right)$, respectively $(\mathrm{F}(1,7)=26.88, \mathrm{p}<0.05$ and $\mathrm{F}(1,7)=15.24$, $\mathrm{p}<0.05)$. At small-scale, the difference between final BMP values confirmed that the hydrolysis of $\mathrm{FW}_{2}$ was more efficient than in the case of $\mathrm{FW}_{1}$ leading to the presence of more easily biodegradable compounds.

Compared to Nilsson Påledal et al. [16] and Lü et al. [17], the effect of storage on BMP was quite different. In the case of Nilsson Påledal et al. [16], BMP values of stored FW remained stable along the experiment when the storage occurred in plastic bags or at $6{ }^{\circ} \mathrm{C}$. The results observed at $6{ }^{\circ} \mathrm{C}$ are related to the low biological activity at low temperatures that reduced organic matter degradation. At $22{ }^{\circ} \mathrm{C}$ in plastic bags, and according to the authors, the stability of BMP can be explained by a "pre-hydrolysis" step occurring in anaerobic conditions that led to a decrease in $\mathrm{pH}$ and an increase in VFA and preserved organic matter content. The phenomenon is close to silage mechanisms used in agriculture to conserve organic matter content of cereals [34]. At $22{ }^{\circ} \mathrm{C}$, for $\mathrm{FW}$ stored in paper bags, BMP values significantly decreased from 135 to $75 \mathrm{NmL}_{\mathrm{CH}^{4}} / \mathrm{g}$ of fresh FW. This trend is due to a loss of water and VS content in 
samples because of the high permeability of water for paper (compared to plastics or glass) which eased water evaporation during storage. Lü et al. [17], on the other hand, found that storage increased BMP values from 61 to $159 \mathrm{NmL}_{\mathrm{CH} 4} / \mathrm{g}$ of fresh FW. Because their experiment was performed in small-scale reactors ( $50 \mathrm{~mL}$ centrifuge tube) with grinded $\mathrm{FW}$, the results are hardly comparable to the present study and differences are attributed to the scaling. Storage of FW at equivalent scale was studied by Fisgativa et al. [20] and showed consistent results with the present study. In this case, FW was stored during 4 days at room temperature at four different oxygen concentrations $(0,5,10$ and $20 \%)$ and BMP values significantly decreased of $7 \%$ after 4 days of storage.

However, even if storage seemed to have improved BMP values, the loss of solid mass during storage has induced a loss in the initial maximum volume of methane that could have been produced. Figure $8 \mathrm{~B}$ represents the real proportion of methane volumes that would have been produced if the solid fraction of stored FW had been digested without mass adjustment (conversely to BMP tests where the same mass is applied in each trial). Results showed that for the first trial (10 L-FW1) the lowest volume of methane would be produced with FW stored for 3 days and 2 weeks as only 69 and $68 \%$ of the initial methane volume would have been produced. After one week of storage, $90 \%$ of the maximum volume of methane could be produced with the corresponding FW. In the light of standard-deviations values, the optimum storage period prior to $\mathrm{AD}$ is between 6 and 10 days. The small-scale experiment of the second trial $\left(10 \mathrm{~L}-\mathrm{FW}_{2}\right)$ showed that about $75 \%$ of the initial methane volume possibly available could be produced after two weeks of storage. The large-scale experiment $\left(300 \mathrm{~L}-\mathrm{FW}_{2}\right)$ showed a methane recovery yield of $95 \%$ after storage which was not significantly different from the volume of methane potentially available initially $(\mathrm{F}(1,7)=0.30, \mathrm{p}>0.05)$. This trial also displayed the lowest loss of initial carbon because of a low hydrolysis performance compared to the small-scale experiments. These results confirmed that small-scale FW storage leads to higher levels of aerobic degradation.

\section{Conclusions}

Storage significantly influenced the physical-chemical characteristics of FW due to the spontaneous hydrolysis of the substrate. During the storage, an aerobic biological activity was recorded. Such aerobic activity triggered the fast liquefaction of the FW, the release of gaseous compounds and supported the production of organic acids including lactic acid.

Depending on the substrate and the scale of storage, the hydrolysis was more or less effective and part of the initial carbon present in the FW was lost. Overall, the loss of initial carbon was less than 7\% (Table 5) and attained lowest values in the case of large-scale storage, with a total loss of $0.7 \%$. The limited loss observed at large-scale was caused by raise in temperature, which dried out the FW and limited the microbial activity. Nevertheless, considering the gap in mass balances and measurement uncertainties, an acceptable carbon loss value during storage should be around $10 \%$.

The change in physical-chemical characteristics also influenced the BMP because of the presence of lactic acid that is inhibitory for methane production. If impossible to avoid, one week represents, in the condition tested in this study, an optimal storage time as the increase in BMP value compensates the loss of organic matter. Large-scale storage methods, such as the bring point model, are recommended as they exhibit lower loss of subsequent methane volume potential compared to small-scale storage.

Beyond the impact of different storage methods on anaerobic digestion that was studied in this article, the data of gaseous emission collected could be of valuable interest to study the environmental impact of biowaste collection systems using the life cycle assessment (LCA) method.

Acknowledgements This work was done as part of the DECISIVE project funded by the European Union's Horizon 2020 research and innovation program under Grant Agreement No. 689229.

OpenAccess This article is distributed under the terms of the Creative Commons Attribution 4.0 International License (http://creativeco mmons.org/licenses/by/4.0/), which permits unrestricted use, distribution, and reproduction in any medium, provided you give appropriate credit to the original author(s) and the source, provide a link to the Creative Commons license, and indicate if changes were made.

\section{References}

1. EEA: Environmental indicator report 2017 - Priority objective 2 - Recycling of municipal waste. In: Agency, E.E. (ed.). vol. No 21/2017. (2017)

2. Andreasi Bassi, S., Christensen, T.H., Damgaard, A.: Environmental performance of household waste management in EuropeAn example of 7 countries. Waste Manag. 69, 545-557 (2017). https://doi.org/10.1016/j.wasman.2017.07.042

3. Stenmarck, A.s., Jensen, C., Quested, T., Moates, G.: Estimates of European food waste levels. In: FUSIONS EU project. (2016)

4. Ravindran, R., Jaiswal, A.K.: Exploitation of food industry waste for high-value products. Trends Biotechnol. 34(1), 58-69 (2016). https://doi.org/10.1016/j.tibtech.2015.10.008

5. Wang, Q., Yamabe, K., Narita, J., Morishita, M., Ohsumi, Y., Kusano, K., Shirai, Y., Ogawa, H.I.: Suppression of growth of putrefactive and food poisoning bacteria by lactic acid fermentation of kitchen waste. Process Biochem. 37(4), 351-357 (2001). https://doi.org/10.1016/S0032-9592(01)00217-5

6. Zhang, C., Su, H., Baeyens, J., Tan, T.: Reviewing the anaerobic digestion of food waste for biogas production. Renew. Sustain. Energy Rev. 38, 383-392 (2014). https://doi.org/10.1016/j. rser.2014.05.038

7. Edwards, J., Othman, M., Crossin, E., Burn, S.: Life cycle assessment to compare the environmental impact of seven contemporary 
food waste management systems. Bioresour. Technol. 248, 156173 (2018). https://doi.org/10.1016/j.biortech.2017.06.070

8. Gao, A., Tian, Z., Wang, Z., Wennersten, R., Sun, Q.: Comparison between the technologies for food waste treatment. In: Energy Procedia 2017, pp. 3915-3921

9. Evangelisti, S., Lettieri, P., Borello, D., Clift, R.: Life cycle assessment of energy from waste via anaerobic digestion: a UK case study. Waste Manag. 34(1), 226-237 (2014). https://doi. org/10.1016/j.wasman.2013.09.013

10. Wellinger, A., Wyder, K., Metzler, A.E.: Kompogas-a new system for the anaerobic treatment of source separated waste. Water Sci. Technol. 27(2), 153-158 (1993)

11. Six, W., De Baere, L.: Dry anaerobic conversion of municipal solid waste by means of the Dranco process. Water Sci. Technol. 25(7), 295-300 (1992)

12. Fruteau de Laclos, H., Desbois, S., Saint-Joly, C.: Anaerobic digestion of municipal solid organic waste: valorga full-scale plant in Tilburg, the Netherlands. Water Sci. Technol. 36(6-7), 457-462 (1997). https://doi.org/10.1016/S0273-1223(97)00555-6

13. Walker, M., Theaker, H., Yaman, R., Poggio, D., Nimmo, W., Bywater, A., Blanch, G., Pourkashanian, M.: Assessment of micro-scale anaerobic digestion for management of urban organic waste: a case study in London, UK. Waste Manag (2017). https:// doi.org/10.1016/j.wasman.2017.01.036

14. Juárez-Hernández, S., Castro-González, A.: Design and economic evaluation of a prototype biogas plant fed by restaurant food waste. Int. J. Renew. Energy Res. 5(4), 1122-1131 (2015)

15. Manns, D., Schermuly, J., Kjerulf Petersen, L., Körner, I.: Survey on waste collection systems with evaluations for decentralised applications. In: DECISIVE H2020 EU project. (2017)

16. Nilsson Påledal, S., Hellman, E., Moestedt, J.: The effect of temperature, storage time and collection method on biomethane potential of source separated household food waste. Waste Manag. 71, 636-643 (2018). https://doi.org/10.1016/j.wasma n.2017.05.034

17. Lü, F., Xu, X., Shao, L., He, P.: Importance of storage time in mesophilic anaerobic digestion of food waste. J. Environ. Sci. (China) (2016). https://doi.org/10.1016/j.jes.2015.11.019

18. Fisgativa, H., Tremier, A., Dabert, P.: Performance of coupling an aerobic pre-treatment and solid-state anaerobic digestion of food waste. Paper presented at the 7th International Conference on Engineering for Waste and Valorization, B., Prague, Czech Republic, July 2-5, 2018

19. Portejoie, S., Martinez, J., Guiziou, F., Coste, C.M.: Effect of covering pig slurry stores on the ammonia emission processes. Bioresour. Technol. 87(3), 199-207 (2003). https://doi.org/10.1016/ S0960-8524(02)00260-2

20. Fisgativa, H., Tremier, A., Saoudi, M., Le Roux, S., Dabert, P.: Biochemical and microbial changes reveal how aerobic pre-treatment impacts anaerobic biodegradability of food waste. Waste Manag. 80, 119-129 (2018). https://doi.org/10.1016/j.wasma n.2018.09.011

21. Fisgativa, H., Tremier, A., Dabert, P.: Characterizing the variability of food waste quality: a need for efficient valorisation through anaerobic digestion. Waste Manag. 50, 264-274 (2016). https:// doi.org/10.1016/j.wasman.2016.01.041

22. APHA: Standard Methods for the Examination of Water and Wastewater, 22nd edn. American Water Works Association, In. American Public Health Association (2012) Water Environment Federation
23. Bareha, Y., Girault, R., Jimenez, J., Trémier, A.: Characterization and prediction of organic nitrogen biodegradability during anaerobic digestion: a bioaccessibility approach. Bioresour. Technol. 263, 425-436 (2018). https://doi.org/10.1016/j.biortech.2018.04.085

24. Peu, P., Béline, F., Martinez, J.: Volatile fatty acids analysis from pig slurry using high-performance liquid chromatography. Int. J. Environ. Anal. Chem. 84(13), 1017-1022 (2004). https://doi. org/10.1080/03067310412331303217

25. Wang, X., Selvam, A., Lau, S.S.S., Wong, J.W.C.: Influence of lime and struvite on microbial community succession and odour emission during food waste composting. Bioresour. Technol. 247, 652-659 (2018). https://doi.org/10.1016/j.biortech.2017.07.091

26. Manu, M.K., Kumar, R., Garg, A.: Performance assessment of improved composting system for food waste with varying aeration and use of microbial inoculum. Bioresour. Technol. 234, 167-177 (2017). https://doi.org/10.1016/j.biortech.2017.03.023

27. Plessas, S., Bekatorou, A., Koutinas, A.A., Soupioni, M., Banat, I.M., Marchant, R.: Use of Saccharomyces cerevisiae cells immobilized on orange peel as biocatalyst for alcoholic fermentation. Bioresour. Technol. 98(4), 860-865 (2007). https://doi. org/10.1016/j.biortech.2006.03.014

28. Loyon, L., Guiziou, F., Beline, F., Peu, P.: Gaseous Emissions (NH3, N2O, $\mathrm{CH} 4$ and $\mathrm{CO} 2$ ) from the aerobic treatment of piggery slurry-Comparison with a conventional storage system. Biosys. Eng. 97(4), 472-480 (2007). https://doi.org/10.1016/j.biosystems eng.2007.03.030

29. Ye, J., Li, D., Sun, Y., Wang, G., Yuan, Z., Zhen, F., Wang, Y.: Improved biogas production from rice straw by co-digestion with kitchen waste and pig manure. Waste Manag. 33(12), 2653-2658 (2013). https://doi.org/10.1016/j.wasman.2013.05.014

30. Zhao, N., Yu, M., Wang, Q., Song, N., Che, S., Wu, C., Sun, X.: Effect of ethanol and lactic acid pre-fermentation on putrefactive bacteria suppression, hydrolysis, and methanogenesis of food waste. Energy Fuels. 30(4), 2982-2989 (2016). https://doi. org/10.1021/acs.energyfuels.5b02779

31. Fisgativa, H., Tremier, A., Le Roux, S., Bureau, C., Dabert, P.: Understanding the anaerobic biodegradability of food waste: relationship between the typological, biochemical and microbial characteristics. J. Environ. Manage. 188, 95-107 (2017). https:// doi.org/10.1016/j.jenvman.2016.11.058

32. Wang, Q., Narita, J., Xie, W., Ohsumi, Y., Kusano, K., Shirai, Y., Ogawa, H.I.: Effects of anaerobic/aerobic incubation and storage temperature on preservation and deodorization of kitchen garbage. Bioresour. Technol. 84(3), 213-220 (2002). https://doi. org/10.1016/S0960-8524(02)00062-7

33. Wei, Y., Zhao, Y., Shi, M., Cao, Z., Lu, Q., Yang, T., Fan, Y., Wei, Z.: Effect of organic acids production and bacterial community on the possible mechanism of phosphorus solubilization during composting with enriched phosphate-solubilizing bacteria inoculation. Bioresour. Technol. 247, 190-199 (2018). https://doi. org/10.1016/j.biortech.2017.09.092

34. Peach, W.J., Dodd, S., Westbury, D.B., Mortimer, S.R., Lewis, P., Brook, A.J., Harris, S.J., Kessock-Philip, R., Buckingham, D.L., Chaney, K.: Cereal-based wholecrop silages: A potential conservation measure for farmland birds in pastoral landscapes. Biol. Conserv. 144(2), 836-850 (2011). https://doi.org/10.1016/j.bioco n.2010.11.017

Publisher's Note Springer Nature remains neutral with regard to jurisdictional claims in published maps and institutional affiliations. 